https://doi.org/10.46344/JBINO.2021.v10i04.10

\title{
PROXIMATE, ELEMENTAL COMPOSITION AND ANTIMICROBIAL ANALYSIS OFAVOCADO (Persea americana) SEED
}

\author{
Ogbuagu ,Adaora Stella Marris., Ukachukwu, Chidimma Esther and Okoye Chinedu Innocent* \\ Department of Pure and Indistrial Chemistry, Nnamdi Azikiwe University, P.M.B 5026, Awka, Anambra State, Nigeria.
}

(Received on date: 01.07.2021

Date of Acceptance: 15.07.2021

Date of publication: 30.07 .2021$)$

\begin{abstract}
The seed of Persea americana (Avocado Seed) was analyzed for its Proximate, Element Composition and Anti-Microbial Properties in accordance with the Association of Analytic Chemistry method, Atomic Absorption Spectrometric method and Standard Method $f$ Antimicrobial determination respectively. The Proximate analysis indicated the presence of Cruc fibre (6.56\%), Protein (1.4\%), Fat (26.72\%), Ash (3.4\%), Moisture Content (8.3\%) and Carbohydra $(53.09 \%)$ while the Elemental analysis showed the presence of Cadmium (0.013ppm), Calciu (6.645ppm), Nickel (1.0733ppm), Sodium (31.724ppm) and Iron (1.387ppm). The result showed th Cadmium fell within the recommended standard $(0.01 \mathrm{ppm})$. The Efficacy of Antimicrob activities of Aqueous and n-hexane extract was carried out against different fungi (Candic albican and Aspergillus niger), and bacteria (Escherichia coli, Proteus, Streptococcus pyoger and Staphylococcus aureus). The results obtained from both extracts showed no significant Ar microbial activities against the tested organisms. Nevertheless, Avocado seed which is norma discarded as a waste is a rich source of nutrients.
\end{abstract}

Keywords: Persea Americana, Nutritional values, Elemental Composition and Anti-microbial properties. 


\section{INTRODUCTION}

Avocado is the common name for the herbaceous plants of genus Persea. Also commonly known as alligator pear or aguacate, it is scientifically known as Persea americana of the family Lauraceal. The word avocado comes from the Aztec word "ahuacati" which is translated in Spaniard as agucate, meaning "testicle" due to its shape

(Padma and Sunil 2015). It is a tropical fruit that originated from America. Avocado is classified as an evergreen, although some varieties lose their leaves for a short time before flowering. The fruit is a berry, consisting of a single large seed, surrounded by a buttery pulp. It contains 3$30 \%$ oil (Florida varieties range from $3-15 \%$ ). The

seed is oblate, round, conocal or ovoid, 5 $6.4 \mathrm{~cm}$ long. They are hard and heavy, ivory in colour but enclosed in two brown, thin, papery seed coats often adhering to the flesh cavity, while the seed slips out readily. (Orwa et al., 2009).

The avocado leaf, stem fruit and peel have biological activities scientifically proven (Miranda et al. 1997; Adeyemi et al., 2002). The pulp of avocado has been reported to have beneficial cardiovascular health effect. Avocado oil is used for dermatological applications and its unsaponifiable portion is reported to have beneficial effects against osteoarthritis. Currently, the seed represents an under- utilized resource and a waste issue for avocado processors (Haas 1951, Dabas et al., 2013; Ogbuagu and Okoye, 2020).

Table 1: Scientific classification of Persea amaericana (Daurte et al., 2016).

\begin{tabular}{|l|l|l|}
\hline Rank & $\begin{array}{l}\text { Scientific } \\
\text { name }\end{array}$ & $\begin{array}{l}\text { Common } \\
\text { name }\end{array}$ \\
\hline Kingdom & Plantae & Plant \\
\hline Subkingdom & Tracheobionta & Vascular plant \\
\hline Supervision & Spermatophyta & Seed plant \\
\hline Division & Magnoliophyta & Flowering plant \\
\hline Class & Magnoliopsida & Dicotyledons \\
\hline Subclass & Magnoliidae & \\
\hline Order & Laurales & \\
\hline Family & Lauracease & Laurel family \\
\hline Genus & Persea & Bay \\
\hline Species & Pearsea & avocado \\
& Americana & \\
\hline
\end{tabular}

There is ethno-pharmacological information on the use of seeds for the treatment of health related conditions, especially in South American countries where avocados are endemic and currently grown on a large scale. Current research has shown that avocado seed may improve hypercholesterolemia and be useful in the treatment of hypertension, inflammatory condition and diabetes. The avocado seed are rich in phenolic compounds and these play a role in the pubative health effects. Avocado seed oils have also been reported to be used in healing of skin eruptions (Swisher, 1988; Ogbuagu and Okoye, 2020).

Historically, extracts of avocado seed were also used as ink for writing and research 
has explored the potential colourant properties of polyphenol oxidase produced coloured avocado seed extract (Dabas, 2013; Ogbuagu and Okoye, 2020).

Phytochemical studies of the avocado seed allowed the identification of several classes of active compounds such as flavonoid, anthocyanins condensed tannins, alkaloids and triterpenoids in methanolic extract while sterols and triterpenes were detected in the hexane extract (Leite et al., 2009).

The use of avocado in traditional herbal medicine can be attributed to its pharmacological activity (Padma and Sunil, 2015). Seed and leaf extracts have been used for variety of medical application including treatment of diarrhoea, dysentery and as an antibiotic (Lahar and Whiley 2002). It contains nutrients which are beneficial in the synthesis of skin protein called collagen (Ding et al., 2007). The fruit is considered one of the most potent anti-oxidant fruit in the world because of its high content of mono saturated fats (Lin et al., 2009), thus, people consuming a special avocado based diets showed lower cholesterol levels. It is noteworthy that enthnopharmcology of Aztec and Maya cultures used decots of avocado seeds as a potent agent to treat mycotic and parasitic infection (Oberlies et al., 1998). Avocado seeds preparations are traditionally used as anti-inflammatory. Some lipids isolated from the avocado fruits have shown selective activity against human prostate Aden carcinoma (Oberlies et al., 1998). Avocado fruits have a skin healing effects which may be due to the positive influence on fatty acid (Carranza et al., 1995). The powdered seed is believed to cure dandruff. An ointment made of the pulverised seed is used as a facial rubefacient. Oil extracted from the seed has been applied on skin eruptions.

\section{MATERIALS AND METHODS}

Materials: The Persea americana fruits were obtained at various locations from Nnaba village in Awka-Etiti, Anambra State, Nigeria. It was identified by the herbarium curator of the Botany Department, Nnamdi Azikiwe University, Awka, Anambra State, Nigeria. All reagents used were of analytical grade.

Sample Preparation: The fruit was left to ripe and the edible part consumed. The seed were manually cut into pieces, after which it was sundried for seven days and then pulverized to powdered form. Only the undamaged seed were chosen.

Moisture Content Determination: A crucible was washed and dried in the oven at $105^{\circ} \mathrm{C}$ for 30 minutes. It was cooled in the dessicator and weighed empty. 2.291g of the sample was weighed into crucible and left in the oven at $105^{\circ} \mathrm{C}$ for 24 hours (to achieve maximum moisture content). This was later removed, cooled in the dessicator and weighed.

$\%$ moisture content $=$

$$
\frac{W_{1}-W_{2}}{W_{3}} \times 100
$$

Where; $w_{1}=$ weight of crucible + sample before drying 
$w_{2}=$ weight of petri dish and sample after drying

$\mathrm{w}_{3}=$ weight of sample.

Crude Protein Determination: This involved the digestion of sample with hot concentrated sulphuric acid in the presence of a metallic catalyst (selenium powder). Then the organic nitrogen in the sample was reduced to ammonium and was retained in the solution as ammonium sulphate. This was then made alkaline, and then distilled to release the ammonia. The ammonia was trapped in dilute acid and then titrated.

$0.5 \mathrm{~g}$ of the sample was gently weighed into a $30 \mathrm{ml}$ kjehdal flask and then the flasks were stoppered and shaken. $0.5 \mathrm{~g}$ of the kjedahl catalyst mixture and the mixture was digested using a heating mantle. Digestion was continued until a clear Solution appeared. The clear solution was then allowed to stand for 30 minutes and allowed to cool. The digested sample was made up to $100 \mathrm{ml}$ with distilled water to avoid caking and then $50 \mathrm{ml}$ was transferred to the kjadahl distillation apparatus. A $100 \mathrm{ml}$ receiver flask containing $5 \mathrm{ml}$ of $2 \%$ boric acid and indicator mixture containing 5 drops of bromocresol blue and 1 drop of methylene blue was placed under a condenser of the digested sample in the apparatus and distillation so that the tap was about $20 \mathrm{~cm}$ inside the solution. $5 \mathrm{ml}$ of $40 \%$ sodium hydroxide was added to the digested sample in the apparatus and distillation commenced immediately until 50 drops gets into the receiver flask, after which it was titrated to pink colour using $0.01 \mathrm{~N}$ hydrochloric acid.

Calculation:

$\%$ Nitrogen $=$ titre value $\times 0.01 \times 14 \times 4$

$\%$ Protein $=\%$ Nitrogen $\times 6.25$

Ash Content: Ash is the inorganic residue obtained by burning off the organic matter of feedstuff at $500^{\circ} \mathrm{C}$. $2 \mathrm{~g}$ of the wet sample was weighed into a washed, dried and weighed platinum and placed in a muffle furnace at $500^{\circ} \mathrm{C}$ for 3 hours or until whitish grey ash is obtained. The sample was cooled in a dessicator after burning and then weighed.

Calculations:

$$
\% \text { Ash content }=\frac{W_{3}-W_{1}}{W_{2}-W_{1}}
$$

Where; $W_{1}=$ weight of empty platinum crucible

$\mathrm{W}_{2}=$ weight of platinum crucible + sample before burning

$$
\mathrm{W}_{3}=\text { weight of platinum }+ \text { ash }
$$

Crude Fibre Determination: $2.014 \mathrm{~g}$ of the sample was weighed and was defatted with $1.26 \mathrm{~g}$ of $\mathrm{NaOH}$ that was dissolved in $100 \mathrm{ml}$ of distilled water. The solution was boiled for 30minutes and was filtered through a linen on a fluted funnel. The residue was transferred to a beaker containing $1.26 \mathrm{~g}$ of sulphuric acid and was made up to $100 \mathrm{ml}$ with distilled water and boiled again for 30 minutes. The solution was filtered and the residue was transferred into a crucible which was then 
dried in an oven for $1 \mathrm{hr}$ at $100^{\circ} \mathrm{C}$ after which was cooled and weighed $\%$ crude fibre $=$

$\frac{\text { weight of fibre }}{\text { Weight of sample }} \times 100$

Crude Fat (Ether Extract): The ether extract of a feed represents the fat and oil in the feed and is carried out by continuously extracting a food with non-polar organic solvent such as petroleum ether for 1 hour or more, using the soxhlet extractor.

$250 \mathrm{ml}$ clean boiling flasks was dried in oven at $110^{\circ} \mathrm{C}$ for 30 minutes and was allowed to cool and weighed. $300 \mathrm{ml}$ of anhydrous diethyl ether of boiling point of $40-60^{\circ} \mathrm{C}$ is placed in the flask. $2.002 \mathrm{~g}$ of the sample was weighed into a thimble and the thimble is plugged tightly with cotton wool. The thimble with the content is placed into the extractor; the ether in the flask is then heated. As the ether vapor reaches the condenser through the side arm of the extractor, it condenses to liquid and drops back into the sample in thimble, the ether soluble substances are dissolved and are carried into solution through the siphon tube back into the flask. The extraction continues for at least 4 hours. The thimble is removed and most of the solvent is distilled from the flask into the extractor. The flask is then disconnected and placed in an oven at $105^{\circ} \mathrm{C}$ for 1 hour, cooled in dessicator and weighed.

$\%$ of fat $=$

Weight of fat $\times 100$
Weight of samples

Mineral Composition Analysis: The minerals were determined using a solution that was obtained by dry ashing the sample at $550^{\circ} \mathrm{C}$ and dissolving it in distilled water that contains $10 \mathrm{ml}$ of concentrated hydrochloric acid in a volumetric flask. $\mathrm{Na}$, $\mathrm{Ca}, \mathrm{Fe}, \mathrm{Cd}$ and $\mathrm{Ni}$ contents were determined using Varian AA240 Atomic Absorption Spectrometer according to the method of APHA 1995 (American Public Health Association).

\section{Antimicrobial Analysis:}

Preparation of media: $36 \mathrm{~g}$ of Nutrient Agar was weighed and dissolved in $100 \mathrm{ml}$ of water which was then boiled and autoclaved for 30 minutes. The media was allowed to cool to about $40^{\circ} \mathrm{C}$ and was poured into the petri-dish and then allowed to set on the bench.

Culturing of Media: The media was bored at the centre using core borer; the wire loop was flamed and used to transfer organisms from the stock culture into the media by streaking. 2 drops each of $n$ hexane and aqueous extract of avocado seed were transferred into the incubator for 24hours (bacterial) and 48 hours for fungi after which the result was read.

\section{RESULTS AND DISCUSIION}

Proximate Analysis Results: The Proximate analysis on the seed of Persea Americana as seen in table 2 above showed that the crude fibre content is $6.56 \%$ which tallies with the study carried out by (Dreher and Davenport, 2013) and this shows that its 
ingestion will help to reduce blood cholesterol level, the risk of bowel cancer and gall stones and it can also serve as a good supplement for weight loss. The relatively high fat content $26.72 \%$ signifies that the seed is a good source of oil, however this is higher than the value $21.63 \%$ as reported by (Ogbuagu and Okoye, 2020); this could be as a result of difference in plant species and varying time of drying. The moisture content $8.83 \%$ which tallies with the study performed by (Arukwe et al, 2012) but is below the stipulated moisture content of $13-15 \%$ and this could be an added advantage to the shelf life of the seed, given that values exceeding $15 \%$ might lead to the seed developing undesirable moulds and fungus. The total ash content of $3.4 \%$, which

Table 2: Result of the Proximate Analysis

Parameter Composition

Moisture Content

$8.83 \%$

Ash Content

$3.4 \%$

Crude Fiber

$6.56 \%$

Fat Content

$26.72 \%$

Carbohydrate

$53.09 \%$

Crude protein

$1.4 \%$ carbohydrate content of $53.09 \%$ indicates that it is a good source of starch in food and can be used as flour for baking e.g. biscuit (Mahawan et al, 2015).

Elemental Analysis Result: The highest concentrated metal is sodium (31.725ppm) as shown in table 3, while the lowest is cadmium (0.013ppm). The value obtained for sodium tallies with the study carried out by (Morais et al, 2017), which is higher than the WHO recommended standard, as well as iron (1.387ppm). The concentrations of calcium (6.645ppm), cadmium (0.013ppm) and Nickel (1.073) all fell within the WHO recommended standard.

Table 3: Mineral (Elemental) Composition of Avocado Seed

\begin{tabular}{lll}
\hline Parameters & $\begin{array}{l}\text { Concentration } \\
\text { (ppm) }\end{array}$ & $\begin{array}{l}\text { WHO } \\
\text { Recomended } \\
\text { Standard } \\
\text { (ppm) }\end{array}$ \\
\hline Calcium & 6.645 & $\leq 10$ \\
Sodium & 31.725 & $\leq 5$ \\
Cadmium & 0.013 & $\leq .01$ \\
Iron & 1.387 & $\leq 1.0$ \\
Nickel & 1.073 & $\leq .03$ \\
\hline
\end{tabular}

Antimicrobial Analysis Results: From the result of the analysis (table 4), it was found that the hexane and aqueous extract of Persea americana seed does not inhibit the growth and hence does not have any antimicrobial activity for the selected organism.

tallies with the study carried out by (Talabi et al, 2016) showed that Persea Americana seed contains less inorganic compounds, while the protein content of $1.4 \%$ signifies a very low protein content. The 
Table 4: Antimicrobial activities of $n$-hexane and aqueous extract

\begin{tabular}{lll}
\hline Test organism & $\begin{array}{l}\text { Hexane } \\
\text { extract }\end{array}$ & $\begin{array}{l}\text { Aqueous } \\
\text { extract }\end{array}$ \\
\hline Candida & - & - \\
Aspergillus & - & - \\
Nnniger & & \\
E.coli & - & - \\
Proteus & - & - \\
Streptococuspyo & - & - \\
gene & & \\
Staphylococus & - & - \\
aureus & & \\
\hline
\end{tabular}

\section{CONCLUSION}

Based on the results of the analysis, as summarized in tables 2,3 and 4 , the following conclusions can be drawn.

Avocado seed contains a diverse number of nutrients and elemental in varying proportions. The high carbohydrate content of seed makes it a good source of energy food; the relatively high fat content could increases the amount of HDL Cholestrol (good cholesterol) in the blood and liver lipids and therefore could be a good source of cooking oil and in the production of margarine.

Sodium controls the body water balance and plays a role in muscle contraction but its high content in avocado seed poses the threat of increasing blood volume in the body when consumed, which in turn raises blood pressure. The calcium content could help in blood clotting, muscle contraction and in metabolic processes in certain enzymes. Calcium is also capable of assuming a corrective role if some inorganic elements such as sodium and potassium are excess in the body. Iron facilitates the oxidation of carbohydrates, fats and proteins and therefore contributes significantly to the prevention of anemia. Iron also plays an important role in the oxidative processes of respiration in living organisms and also in the normal functioning of the central nervous system. The slightly higher content of iron however, can cause liver toxicity and increase the risk of liver failure or hepatocellullar carannions in humans. Nickel and cadmium are present in the right proportions and although they are regarded as essential metals which the body needs in very small quantities, they are also very toxic but shouldn't pose any significant threat on consuming the seed.

The $n$-hexane and aqueous extract of the seed did not show any anti-microbial activity for the selected organisms as shown in table 4. However, it is a potential source of nutrients and medicinal compounds and could find many uses in clinical application and food processing.

\section{REFERENCES}

Padma, T and Sunil, S., (2015). A Review on Persea americana mill. International Journal of Pharm Tech Research, 8 (6), 72 77.

Orwa, C.A.M., Kindt, R., Jamnadass, R and Anthony, S., (2009) Agroforestry Database.Three References and Selection Guide, 4: 1- 4. 
Mirinda, M. F. S., Almeida, A.P., Costa, S.S., Sanntos, M.G.M., Lagrota, M.H.C and Wig, M.D.J., (1997). In Vitro Activity of Extracts of Perseaamericana Leaves on Acyclovir Resistant and Phosphonoacetic Resistant Herpes simpler virus. Phytomedicine, 4: 347 $-352$

Adeyemi, O.O, Okpo, S.O and Ogunti, O.O., (2002). Analgesic and Antiinflammatory Effects of the Aqueous Extract of Leaves of Persea americana Mill.Fitoterapia, 73: $375-380$.

Haas, R.C., (1951). Variation in the Composition of Avocado Seed.California Avocado Society, 35: 139-152.

Dabas, D.J Rachel, M.S., Ziegler, G.R and Lambert, J.D., (2013). Avocado Seed as a Source of Bioactive Phytochemicals. Current Pharmaceutical Design, 19 (34): 20 $-35$.

Ogbuagu, A., Okoye, C. Physico-chemical Characterization of Avocado (Persea Americana Mill.) Oil from Tree Indonesian Avocado Cultivars. Progress in Chemical and Biochemical Research, 2020; (3): 3945.

Duarte, P.F, Chaves, M.A. and Borges, C.D., (2016). Avocado: Characteristic, Health Benefits and uses. International Journal of Food Technology, 46(4): 747 -754.

Swisher, H. E. (1988). Avocado Oil. J. Am. Oil Chem., 65 (1988) 1705.
Leite, J.J.G., Brito, R.A., Sidrim, J.J.C., Bertinni, L. I.M., Marais, S.M and Roacha, M.F.G.J., (2009). Chemical Composition, Toxicity and Larvicidal and Antifungal Activities of Avocado Seed Extract. http://www.lenntech.com (Accessed 10 July, 2017).

Lahay, E and Whiley, A.W., (2002). Irrigation and Mineral Nutrition in the Avocado, Botany, Production and Uses. $A B$ International, U.K, pp. 259 -297

Ding, H., Han, C., Guo, D., Chin, Y.W., Kinghorn, A.D and D'Ambrosio, S.M., (2007). Chemopreventive Characteristics of Avocado Fruit. Semincancer Boil, 17: 386 $-394$.

Lin, X. J., Racette, S. B., Anderson-Spearie, C.L and Ostund, R.E., (2009). Phytosterol Glycosides Reduce Cholesterol Absorption in Humans.Gastrointestinal liver physiol, 296: $931-935$.

Oberlies, N. H., Rogers, L.L., Martin, J.M and McLaughlin, J.L., (1998). Cytotoxic and Insecticidal Constituents of the Unripe Fruit of Persea americana.Nnatu Prod, 61: 781 785.

Dreher, M.L and Davenport, A.J., (2013). Hass Avocado Composition and Potential Health Effect. Critical Review in Food Science and Nutrition, 53(7): 738-750.

Carranza, J., Alvizouri, M., Alvarado, M.R, Chavez, F., Gomez, M and Herrera, J.E., (1995). Effects of Avocado on the Level of Blood Lipids in Patients with Phenotype II 
and IV dyslipidemias. Arch InstCardioll Mex, 65: $342-348$.

Arukwe, U., Amadi, B. A., Duru, M. K. C., Agomuo, E. M., Adindu, E. A., Odika, P. C., Lele, K. C., Egejuru, L and Anudike, J., (2012). Chemical Composition of Persea americana Leaf, Fruit and Seed. International Journal Research Review of Applied Science, 11 (2): 346-347.

Tarabi, J. Y., Osukoya, O. A., Ajayi, O. O and Adegoke, G. O., (2016). Nutritional Composition of Processed Avocado (Perseaamericana Mill) Seeds. Asian Journal of Plant Science and Research, 6(2): 6-12.

Mahawan, M. A., Tenorio, F. N., Gomez, J. A. and Bronce, R. A., (2015). Characterization of Flour from Avocado Seed Kernel. Asia Pacific Journal of Multidisciplinary Research, 3(4): 34-40.

Morais, D. R., Rotta, E. M., Sargi, S. C., Bonafe, E. G., Suzuki, R, M., Souza, N. E., Matsushita, M and Visentainer, J. V., (2017). Proximate Composition, Mineral Contents and Fatty Acid Composition of the Different Parts and Dried Peels of Tropical Fruits Cultivvated in Brazil. Journal of Brazil Chemical Society, 28(2): 308-318. 